DOI 10.7764/rcia.v45i1.1897

\title{
Chemical Composition and Antifungal and Antibacterial Activity of Mentha spicata L. Volatile Oil
}

\author{
Yusuf Bayan ${ }^{1}$, and Mustafa Küsek ${ }^{2}$ \\ ${ }^{1}$ Ahi Evran University, Faculty of Agriculture, Department of Plant Protection, 40200 Kırşehir-Turkey \\ ${ }^{2}$ Kahramanmaras Sutcu Imam University, Faculty of Agriculture, Department of Plant Protection, 46100 \\ Kahramanmaras-Turkey
}

\begin{abstract}
Y. Bayan, and M. Küsek. 2018. Chemical Composition and Antifungal and Antibacterial Activity of Mentha spicata L. Volatile Oil. Cien. Inv. Agr. 45(1): 64-69. In this study, we researched the chemical composition and the antifungal and antibacterial activity of volatile oil from Mentha spicata. The Gas chromatography/mass spectrometry (GC/MS) analysis of M. spicata showed that the main component was carvone (56.94\%), followed by limonene (11.63\%), sabinene hydrate (7.04\%) and caryophyllene (4.06\%). The antifungal activity of the volatile oil from M. spicata L. was determined with respect to plant pathogenic fungi, such as Fusarium oxysporum f. sp. radicis-lycopersici (Sacc.) W.C. Synder \& H.N. Hans (FORL), Rhizoctonia solani J.G. Kühn. (R. solani), Alternaria solani (A. solani), and Verticillium dahliae Kleb ( $V$. dahliae). The volatile oil was shown to have strong antifungal activity against plant pathogenic fungi. The result of the study was that at a dose of $12 \mu \mathrm{L}$ petri $^{-1}$, the volatile oil inhibited $100 \%$ of mycelium growth in $V$. dahliae, A. solani FORL and R. solani. Volatile oil exhibited remarkable activity against the selected bacterial strains of Xanthomonas spp. (ZI365, ZI366, ZI368, ZI370, ZI373, ZI375, ZI376, ZI378).
\end{abstract}

Keywords: Antibacterial, Antifungal, Mentha spicata L., Volatile oils.

\section{Introduction}

The Lamiaceae family contains more than 4000 species in 200 genera. In the Lamiaceae family, mint is one of the most cultivated and aromatic plants. Mint is grown in temperate regions in many parts of the world (South America, Antarctica, Europe and Asia) (Chambers, 1992; Kanatt et al., 2007).

Received Nov 14, 2017. Accepted Mar 05, 2018 Corresponding author: yusufbayan@gmail.com
Mentha leaves have been traditionally used fresh and dried with various spices. Mentha species are comprised of biologically active components, which are used in traditional medicines. Additionally, mint species can be used in traditional medicine for common ailments, such as colds, coughs, sinusitis, fever, bronchitis, and nausea (Starburck, 2001; Dhifi et al., 2011). In addition, the mint plant has been reported to have insecticidal, antimicrobial, antispasmodic, antioxidant and antifungal activities (Papachristos and Stamopoulos, 2001; Shetty 2001; Nosrati, et al., 2011; Karagozlu et al., 2011). 
The main components of the volatile oil of $M$. spicata $\mathrm{L}$. are carvone, limonene, cis-carveol, 1,8 cineol and cis-sabinene hydrate, of which carvone is the most important constituent (Baser, 1993; Wyk and Wink, 2008). The antifungal and antibacterial activities of the volatile oil components have been defined in the literature. Volatile oil molecules are less-produced by the plant, but they act as defense mechanisms against predator attacks, such as pathogens and insects (Bayan and Aksit, 2016; Silva and Câmara, 2013). The objectives of this study were to determine the chemical components of volatile oils from M. spicata $\mathrm{L}$. and to investigate their antibacterial and antifungal activities.

\section{Materials and methods}

\section{Preparation of plant materials and volatile oil}

The M. spicata plant materials were collected from Kirsehir, Turkey in July 2016. The volatile oil was extracted from wet aerial parts by hydrodistillation in a Clevenger's apparatus for $2 \mathrm{~h}$. The volatile oil was obtained from plant materials and was then kept in the dark at $4{ }^{\circ} \mathrm{C}$ until it was used.

Gas chromatography/mass spectrometry (GC) MS) analysis

GC/MS analyses were done in an Agilent Technologies 7890A GC System, 5975C using a TripleAxis Detector mass spectrometer with a built-in Autosampler, with the use of the HP-5MS capillary column $(30 \mathrm{~m} \times 0.25 \mathrm{~mm} \times 0.25 \mathrm{~mm})$. For GC/MS detection, an electron ionization system with an ionization energy of $70 \mathrm{eV}$ was used. Helium was the transporter gas at a flow rate of $1 \mathrm{~mL} \mathrm{~min}^{-1}$. The column temperature program was the same as defined upstairs. As in the gas chromatography, 1.0 L split/splitless (10:1) of the sample, diluted with hexane, was transferred to the clone. Identification of oil components was successful by comparison of their mass spectral fragmentation model by the available mass library (WILLEY and NIST).
In vitro antifungal effect of the volatile oils

The antifungal activities of volatile oil were determined using the agar well diffusion method (Tepe et al., 2005). The Potato Dextrose Agar (PDA) was autoclaved and cooled to $40^{\circ} \mathrm{C}$. Then, it was transferred to $60-\mathrm{mm}$ petri dishes $\left(10 \mathrm{ml}\right.$ petri $\left.^{-1}\right)$. Next, 5-mm-diameter wells were opened on the PDA within the petri dishes. The plant volatile oils were applied at doses of $0.5,1,2,4,8$ and $12 \mu \mathrm{l}$ petri $^{-1}$ into the wells. Mycelium disks of $5 \mathrm{~mm}$ were then placed at equal distances from these wells. The fungi transferred to the petri dishes were incubated at $22 \pm 2{ }^{\circ} \mathrm{C}$. The inhibition in development was compared tothat in the control group, and percentile mycelial growth was calculated

$$
\mathrm{I}=100 \times(\mathrm{DC}-\mathrm{DT}) / \mathrm{DC}
$$

I: Inhibition percentage compared to the control (mycelium development)

DC: Mycelium development in the control

DT: Mycelium development in volatile oil applications.

Data were analyzed using the One-Way procedure of ANOVA (Windows version of SPSS, release 15.00). Differences among concentrations were compared using Duncan's Multiple Range Test with a level of $p<0.05$.

\section{İn vitro antibacterial activity}

In the plant bacterial sample, eight different Xanthomonas spp. (ZI365, ZI366, ZI368, ZI370, ZI373, ZI375, ZI376, ZI378) strains were isolated from pepper fields in Kahramanmaras, Turkey. The bacteria cultures were grown in nutrient glucose agar solid medium, at $25^{\circ} \mathrm{C}$. After $24 \mathrm{~h}$ of growth, each bacteria strain, at a concentration of $0.1 \mathrm{OD}$ density, was set with a spectrophotometer at 600 $\mathrm{nm}$. Then, they were inoculated on the surface of nutrient glucose agar petri dishes with the aid of a drumstick. Later, filter paper discs $(10 \mathrm{~mm}$ 
in diameter) saturated with $10 \mu \mathrm{l}$ of volatile oil were placed on the surface of each inoculated petri dish. The petri dishes were incubated at $25^{\circ} \mathrm{C}$ for $48 \mathrm{~h}$. Bacteria were evaluated by measuring the undeveloped zone. The experiment was performed with four duplicates and was repeated twice.

\section{Results and Discussion}

\section{Chemical Composition results}

The compounds identified from M. spicata are shown in table 1 . Thirty components, representing $100 \%$ of the total, were identified in M. spicata volatile oil. As the results of GC-MS analysis showed, the main component of $M$. spicata $\mathrm{L}$. volatile oil was Carvone (56.94\%). The main component was followed by Limonene (11.63\%), Sabinene hydrate (7.04\%), Caryophyllene (4.06\%), and Terpinen-4-ol (2.49\%), as shown in table 1.

There is wide diversity in the chemical composition of M. spicata plants around the world. In previous studies, different chemotypes from the volatile oil of $M$. spicata have been described with other main components, with a prevalence of pulegone, carvone, limonene, 1,8-cineole and piperitone (Telci et al., 2004; Morteza-Semnania et al., 2006; Kokkini et al., 1995). The chemical compositions of some differences were observed among volatile oils from $M$. sipicata; the differ-

Table 1. Chemical composition of M. spicata L. volatile oil.

\begin{tabular}{|c|c|c|c|c|c|}
\hline $\begin{array}{l}\text { Compound } \\
\text { number }\end{array}$ & ${ }^{\dagger} \mathrm{RT}(\mathrm{min})$ & ${ }^{\mathrm{N} I}$ & Name & $\%$ & $\begin{array}{l}\text { Methods of } \\
\text { identification }\end{array}$ \\
\hline 1 & 13,098 & 952 & $\beta$-Pinene & 0,45 & RI, ${ }^{\S} \mathrm{MS}$ \\
\hline 2 & 13,283 & 957 & $\beta$-Pinene & 0,45 & RI, MS \\
\hline 3 & 13,472 & 963 & $\beta$-Pinene & 1,07 & RI, MS \\
\hline 4 & 14,465 & 993 & Terpinolene & 0,35 & RI, MS \\
\hline 5 & 14,889 & 1005 & Limonene & 11,63 & RI, MS \\
\hline 6 & 15,018 & 1010 & Eucalyptol & 3,28 & RI, MS \\
\hline 7 & 15,835 & 1035 & $\gamma$-Terpinene & 0,79 & RI, MS \\
\hline 8 & 16,203 & 1046 & Sabinene hydrate & 7,04 & RI, MS \\
\hline 9 & 16,876 & 1065 & Terpinolene & 0,24 & RI, MS \\
\hline 10 & 17,25 & 1075 & 4-Thujanol & 0,54 & RI, MS \\
\hline 11 & 18,089 & 1098 & Terpinolene & 0,31 & RI, MS \\
\hline 12 & 19,648 & 1145 & $\alpha$-Terpineol & 0,37 & RI, MS \\
\hline 13 & 20,047 & 1156 & Terpinen-4-ol & 2,49 & RI, MS \\
\hline 14 & 20,712 & 1175 & Dihydrocarvone & 3,40 & RI, MS \\
\hline 15 & 21,005 & 1183 & Dihydrocarvone & 0,18 & RI, MS \\
\hline 16 & 21,517 & 1196 & Carveol & 0,35 & RI, MS \\
\hline 17 & 22,604 & 1229 & Carvone & 56,94 & RI, MS \\
\hline 18 & 23,431 & 1254 & Carvone oxide & 0,14 & RI, MS \\
\hline 19 & 24,934 & 1297 & Neodihydrocarveol & 0,79 & RI, MS \\
\hline 20 & 25,623 & 1318 & Verbenone & 0,53 & RI, MS \\
\hline 21 & 26,049 & 1332 & Carveol acetate & 0,14 & RI, MS \\
\hline 22 & 26,742 & 1353 & alfa-Copaene & 0,16 & RI, MS \\
\hline 23 & 27,103 & 1364 & $\beta$-Bourbonene & 1,93 & RI, MS \\
\hline 24 & 28,256 & 1398 & Caryophyllene & 4,06 & RI, MS \\
\hline 25 & 28,485 & 1406 & $\beta$-Cubebene & 0,29 & RI, MS \\
\hline 26 & 28,904 & 1420 & $\beta$-Farnesene & 0,53 & RI, MS \\
\hline 27 & 29,284 & 1433 & Caryophyllene & 0,22 & RI, MS \\
\hline 28 & 30,107 & 1459 & $\beta$-Cubebene & 0,96 & RI, MS \\
\hline 29 & 31,214 & 1494 & $\beta$-Cadinene & 0,14 & RI, MS \\
\hline 30 & 33,236 & 1563 & Caryophylene oxide & 0,25 & RI, MS \\
\hline Total & & & 100 & & \\
\hline
\end{tabular}

${ }^{\dagger} \mathrm{RT}$, retention time; ${ }^{\ddagger} \mathrm{RI}$, retention indices; ${ }^{\S} \mathrm{MS}$, Mass spectra 
ences may be due to genotype, environmental conditions or agronomic management, such as harvesting and date (Kokkini et al., 1995; Dhifi et al., 2011; Khan and Ahmad, 2011).

\section{In vitro antifungal results}

The volatile oil of M. spicata was used in the assay. The antifungal inhibition percentages of volatile oil from M. spicata L. on the mycelia growth of $V$. dahliae, A. solani, FORL and $R$. solani are shown in table 2.

The rate of mycelium growth inhibition was shown to vary with different doses. Compared with the control, volatile oil at a dose of $8 \mu \mathrm{L}$ petri $^{-1}$ reduced the mycelium growth of $A$. solani and $R$. solani by $100 \%$. V. dahliae and FORL. mycelium growth was reduced by $57.61 \%$ and $64.09 \%$, respectively. This result showed that, for $V$. dahliae and FORL. volatile oil had antifungal potential, and volatile oil showed a better effect on $A$. solani and $R$. solani at a dose of $8 \mu \mathrm{L}_{\text {petri }}{ }^{-1}$. At a dose of $10 \mu \mathrm{L}$ petri ${ }^{-1}$, the volatile oil blocked the plant pathogen mycelium growth by $100 \%$. The biological activities of volatile oils from the mentha species were shown to have strong antimicrobial and antifungal effects. Additionally, volatile oil from $M$. spicata showed a fungitoxicity effect (Ramesh et al., 2006; Hajlaoui et al., 2009).
Gulluce et al. (2007), in their work on the antimicrobial properties of the volatile oils from Mentha longifolia L. ssp. Longifolia, showed the strong antimicrobial activity of volatile oil against all 30 microorganisms. The antimicrobial effects of volatile oils depend on the species of the compound and its chemical components. Previous studies support our results.

\section{In vitro antibacterial results}

The antimicrobial activity of the volatile oil from M. spicata was studied with a dose of 10 $\mu 1$ petri $^{-1}$ against eight plant pathogenic bacterial strains. The results of the antimicrobial potential of the volatile oil are presented in Table 3. The diameter of the growth inhibition zones ranged from 12 to16 $\mathrm{mm}$ for all the Xanthomonas spp. strains.

M. spicata volatile oil showed remarkable activity against the tested Xanthomonas spp. strains. The highest effect of volatile oil was seen on the ZI365 strain. In previous studies, most researchers reported the antimicrobial, antifungal, and antioxidant properties of volatile oils (Pattnaik et al.,1996; Sacchetti et al., 2005; Gulluce et al, 2007). Gulluce et al. (2007) reported that the volatile oils of $M$. long folio ssp. longifolia showed significant antimicrobial activities against all 15 bacteria, 14 fungi and a yeast species tested. When

Table 2. Antifungal activity values (Inhibition (\%) and Inhibition zone) for M. spicata volatile oil.

\begin{tabular}{|c|c|c|c|c|c|c|c|c|}
\hline \multirow{3}{*}{$\begin{array}{l}\text { Doses } \\
\left(\mu \text { lpetri }{ }^{-1}\right)\end{array}$} & \multicolumn{8}{|c|}{${ }^{\dagger}$ Plant Pathogens } \\
\hline & \multicolumn{2}{|c|}{${ }^{\dagger} \mathrm{R} . \mathrm{s}$} & \multicolumn{2}{|c|}{ A.s } & \multicolumn{2}{|c|}{ FORL } & \multicolumn{2}{|c|}{ V.d } \\
\hline & ${ }^{\ddagger} \mathrm{I}^{(\%)}$ & ${ }^{\S} \mathrm{Iz}{ }^{(\mathrm{mm})}$ & $I^{(\%)}$ & $\mathrm{Iz}^{(\mathrm{mm})}$ & $I^{(\%)}$ & $\mathrm{Iz}^{(\mathrm{mm})}$ & $I^{(\%)}$ & $\mathrm{Iz}^{(\mathrm{mm})}$ \\
\hline (0) N.c & $0.00^{\mathrm{e}^{*}} \pm 0.0$ & 60 & $0.00^{\mathrm{d}} \pm 0.0$ & 60 & $0.00^{g} \pm 0.0$ & 60 & $0.00^{\mathrm{f}} \pm 0.0$ & 60 \\
\hline 0.5 & $0.00^{\mathrm{e}} \pm 0.0$ & 60 & $0.00^{\mathrm{d}} \pm 0.0$ & 60 & $15.08 \mathrm{f} \pm 0.79$ & 50.95 & $28.42^{\mathrm{e}} \pm 2.49$ & 42.94 \\
\hline 1 & $21.11^{\mathrm{d} \pm 1.46}$ & 47.33 & $0.00^{\mathrm{d}} \pm 0.0$ & 60 & $37.73^{\mathrm{e}} \pm 5.02$ & 37.35 & $36.56^{\mathrm{e}} \pm 1.48$ & 38.06 \\
\hline 2 & $34.05^{\mathrm{c}} \pm 2.38$ & 39.57 & $31.39^{\mathrm{c}} \pm 0.96$ & 41.16 & $45.92^{\mathrm{d}} \pm 1.17$ & 32.44 & $43.63^{\mathrm{d}} \pm 0.46$ & 33.82 \\
\hline 4 & $58.75^{\mathrm{b}} \pm 1.22$ & 24.75 & $46.61^{b} \pm 1.33$ & 31.82 & $52.95^{\mathrm{c}} \pm 0.95$ & 28.23 & $50.88^{\mathrm{c}} \pm 1.02$ & 29.46 \\
\hline 8 & $100^{\mathrm{a}} \pm 0.0$ & 0 & $100^{\mathrm{a}} \pm 0.0$ & 0 & $64.09^{b} \pm 1.52$ & 21.54 & $57.61^{\mathrm{c}} \pm 1.99$ & 25.43 \\
\hline 12 & $100^{\mathrm{a}} \pm 0.0$ & 0 & $100^{\mathrm{a}} \pm 0.0$ & 0 & $100^{\mathrm{a}} \pm 0.0$ & 0 & $100^{\mathrm{a}} \pm 0.0$ & 0 \\
\hline
\end{tabular}

According to Duncan's test, the averages with different letters in the same column are different at the significance level of $\mathrm{p}<0.05$

${ }^{\dagger}$ Plant pathogens: R. solani (R.s), A. Solani (A.s), F. oxysporum f. sp radicis-lycopersici (FORL), V. dahliae (V.d), Negative control (N.c). ${ }^{\ddagger}(\%)$ : Mycelium inhibition percentage. ${ }^{\S} \mathrm{Iz}(\mathrm{mm})$ : Mycelium development 
Table 3. Antibacterial activity of volatile oil; pathogen inhibition zone (mm), according to the disk diffusion method.

\begin{tabular}{lccccccccc}
\hline Xanthomonas spp. strains & Control & ZI378 & ZI376 & ZI375 & ZI373 & ZI370 & ZI368 & ZI366 & ZI365 \\
\hline inhibition zone $(\mathrm{mm})$ & 14 & 14 & 13 & 13 & 13 & 13 & 12 & 16 \\
\hline
\end{tabular}

compared with earlier studies, similar results were obtained in our study. Previous studies have supported our findings.

The main conclusions are as follows. In this study, we determined the antibacterial and antifungal activities and chemical composition of volatile oil from M. spicata L. The results of this work have shown that volatile oil from $M$. spicata has strong antifungal activity against plant pathogenic fungi. Additionally, it showed remarkable antibacterial activity. The chemical composition of volatile oil from M. spicata was determined, and its main component was carvone. These studies can be used in the management of plant pathogenic fungi and bacterial disease control.

\title{
Resumen
}

\begin{abstract}
Y. Bayan, y M. Küsek. 2018. Composición química y actividad antifúngica y antibacteriana del aceite volátil Mentha spicata L. Cien. Inv. Agr. 45(1): 64-69. El objectivo del trabajo fue la investigación de la composición química, de la actividad antifúngica y antibacteriana del aceite volátil Mentha spicata. Desde el análisis Cromatografía de gases / espectrometría de masas (GC-MS), el componte principal M. spicata, resulta constituido por carvona (56.94\%), limoneno (11.63\%), hidrato de sabineno (7.04\%) y cariofileno (4.06\%). Se ha ademas detectado la actividad antifúngica del aceite volátil de M. spicata L. Contra hongos patógenos de plantas; Fusarium oxysporum f. sp. radicis-lycopersici (Sacc.) W.C. Synder \& H.N. Hans (FORL), Rhizoctonia solani J.G. Kühn. (R. solani), Alternaria solani (A. solani) y Verticillium dahliae Kleb ( $V$. dahliae). Se ha demostrado una fuerte actividad antifúngica del aceite volátil contra los hongos patógenos de plantas. El resultado del estudio, a una dosis de $12 \mu \mathrm{L}$ petri-1, inhibió el crecimiento del 100\% del micelio de $V$. dahliae, A. solani, FORL y $R$. solani. El aceite volátil exhibió una actividad notable contra las Xanthomonas spp seleccionadas (ZI365, ZI366, ZI368, ZI370, ZI373, ZI375, ZI376, ZI378) aislados bacterianos.
\end{abstract}

Palabras clave: Aceites volátiles, antibacterial, antifúngico, Mentha spicata L.

\section{References}

Baser, K., 1993. Volatile oils of Anatolian Labiatae: a profile. Acta Horticul. 333:217-238.

Bayan, Y., and H. Aksit. 2016. Antifungal Activity of Volatile Oils and Plant Extracts from Sideritis germanicopolitana BORNM. Growin in Turkey. Egypt J Biol Pest Co 26(2):333-337.

Chambers, H. 1992. Mentha: genetic resources and the collection at USDA-ARSNCGR Corvallis. Lam News1 1:3-4.

Dhifi, W., M. Litaiem, N. Jelali, N. Hamdi, and W. Mnif. 2011. Identification of a new chemotye of the plant Mentha aquatica Grown in Tunisia: chemical composition, antioxidant and biological activities of its volatile oil. Journal of Volatile Oil Bearing Plants 14:320-328.

Gulluce M., F. Sahin, M. Sokmen, H. Ozer, D. Daferera, A. Sokmen, M. Polissiou, A. Adiguzel, and H. Ozkan. 2007. Antimicrobial and antioxidant properties of the volatile oils and methanol extract from Mentha longifolia L. ssp. Longifolia. Food Chem 103:1449-56.

Hajlaoui H., N. Trabels, and E. Noumi. 2009. Biological activities of the essential oils and methanol extract of tow cultivated mint species (Mentha longifolia and Mentha pulegium) used in the 
Tunisian folkloric medicine. World J. Microbiol. Biotechnol. 25(12):2227-2238.

Kanatt S.R,. R. Chander, and A. Sharma. 2007. Antioxidant potential of mint (Mentha spicata L.) in radiation-processed lamb meat. Food Chem. 100:451-458.

Karagozlu N., B. Ergonul, and D. Ozcan. 2011. Determination of antimicrobial effect of mint and basil volatile oils on survival of E. coli O157: H7 and S. typhimurium in fresh-cut lettuce and purslane. Food Control 22:1851-1855.

Khan M.S., and I. Ahmad. 2011. Antifungal activity of essential oils and their synergy with fluconazole against drug-resistant strains of Aspergillus fumigatus and Trichophyton rubrum. Appl. Microbiol. Biotechnol. 90(3):1083-1094.

Kokkini, S., R. Karousou, and T. Lanaras. 1995. Essential oils of spearmint (Carvone-rich) plants from the island of Crete (Greece). Biochem. Syst. Ecol. 23(4):425-430.

Morteza-Semnania, K., M. Saeedib, and M. Akbarzadeh. 2006. The volatile oil composition of Mentha aquatica L. Journal of Volatile Oil Bearing Plants 9:283-286.

Nosrati, S., S.A.E. Hosseini, A. Sarpeleh, M.S. Shahrbabak, and Y.S. Shahrbabak. 2011. Antifungal Activity of Spearmint (Mentha Spicata L.) Volatile Oil on Fusarium oxysporum f. sp. radicis-cucumerinum the Causal Agent of Stem and Crown Rot of Greenhouse Cucumber in Yazd, Iran. IPCBEE vol.15(2011) Press, Singapore.

Papachristos, D.P., and Stamopoulos D.C. 2001. Repellent, toxic and reproduction inhibitory effects of volatile oil vapours on Acanthoscelides obtectus (Say) (Coleoptera: Bruchidae). J Stored Prod Res 38(2):117-128

Pattnaik, S., V.R. Subramanyam, and C. Kole. 1996. Antibacterial and antifungal activity of ten volatile oils in vitro. Microbios. 86(349):237-46.

Ramesh, S.Y., K. Sandeep, and D. Anupam. 2006. Antifungal properties of volatile oil Mentha spicata 1. var. MSS-5. Indian J. Crop Science.1:197-200.

Sacchetti, G., S. Maietti, M. Muzzoli, M. Scaglianti, S. Manfredini, M. Radice, and R. Bruni. 2005. Comparative evaluation of 11 volatile oils of different origin as functional antioxidants, antiradicals and antimicrobials in foods. Food Chem 91:621-32.

Shetty, K. 2001. Biosynthesis and medical applications of rosmarinic acid. J Herbs Spices Med Plants 8:161-183.

Silva, C.L., and J.S. Câmara. 2013. Profiling of volatiles in the leaves of Lamiaceae species based on headspace solidphase microextraction and mass spectrometry. Food Res. Int. 51:378-387.

Starburck, J. 2001. Herbs for sleep and relaxation. Men's Health. 16:24-26.

Telci, I., N. Sahbaz, G. Yilmaz, and M.E. Tugay. 2004. Agronomical and chemical characterization of spearmint (Mentha spicata L.) originating in Turkey. Econ. Bot. 58:721-728.

Wyk, B.E., and M. Wink .2008. Rośliny lecznicze świata. Wrocław 206-7. 